\title{
A-luokan aikuiskasvatustiedettä
}

\begin{abstract}
$y$
Artikkelissa professori Anja Heikkinen asemoi aikuiskasvatustiedettä tieteen maastossa ja keskustelee kollegoittensa aiempien puheenvuorojen kanssa. Hän epäilee, että syyllisiä sivistyksellisistä tehtävistä loitontumiseen ja rahoittajien käsitteiden omaksumiseen ei tarvitse etsiä vain yliopiston ja tiedeyhteisön ulkopuolelta.
\end{abstract}

Kelvataanko me? Serge Moskovici ja Ivana Markova (2006) kuvaavat, miten sosiaalipsykologia-oppiainetta tehtiin osana toisen maailmansodan jälkeistä (yhteiskunta)tieteiden amerikanisaatiota. ${ }^{1}$ Sota-ajan Yhdysvalloissa kulttuuriantropologiassa, sosiologiassa ja psykologiassa kehitellyille ryhmädynaamisille ja asennetutkimuksille avautui huikeat markkinat yhteiskuntapolitiikan, hallinnon, liiketoiminnan ja työorganisaatioiden kehittämisessä.

USA:n kautta kierrätetyt opit palasivat Eurooppaan ja jälkijunassa Suomeen 1960-luvulla. Sosiaalipsykologinen "siltatiede" osoitti ihmis- ja yhteiskuntatieteiden hyödyllisyyden työmarkkina- ja muiden yhteiskunnallisten ristiriitojen identifioimisessa ja kontrolloinnissa. Ihmisten ryhmäkäyttäytyminen ja -asenteet pyrittiin määrittelemään objektiivisin muuttujin ja indikaattorein. (emt., Alastalo 2009.) Ylikansallista tieteenalaa tehtäessä teoreettinen keskeneräisyys ja kulttuurierot häivytettiin korostamalla sen metodologista erityisyyttä - kokeellisuutta (psykologinen laboratoriotutkimus) ja kokemuksellisuutta (survey-tutkimus) -, jolloin "kulttuuriset" erot jäisivät hoidettavaksi aineistolähtöisellä analyysillä.
Suomalaisen aikuiskasvatustieteen ja -tutkimuksen historia on ollut kamppailua häpeän ja kelpaamisen välillä. Kun kansanvalistus ja -sivistys eivät kelvanneet sen paremmin Helsingin kuin Turunkaan yliopiston tieteelliseen profiiliin, muotoili Helsingin yliopiston dosentti, työväenopiston rehtori, Yhteiskunnallisen Korkeakoulun yliopettaja ja Kouluhallituksen luottomies Zachris Castrén 1920-luvulla vapaalle sivistystyön mission, jonka piti elähdyttää erityisesti työväen sivistysliikkeen ja työväen- ja kansalaisopistojen toimijoiden uskoa tehtävänsä kansallisvaltiolliseen korvaamattomuuteen.

Urpo Harva asemoitui 1940-luvulla jo tieteensisäisiin kiistoihin määritellessään aikuiskasvatusoppiaineen itselleen läheisten filosofisten ja kasvatustieteellisten oppien perustalta. Tampereen yliopistossa Aulis Alanen kumppaneineen taas kytki aikuiskasvatuksen tieteellisen tutkimuksen ja koulutuksen 1970-luvulla osaksi sosiaalidemokratia-vetoista reformistista yhteiskuntapolitiikkaa.

Kasvatustieteiden tiedekuntaan siirretystä aikuis- ja nuorisokasvatuksen laitoksesta yritettiin vielä rakentaa yhteyksiä myös yhteiskuntatieteelliseen ja työelämän 
tutkimukseen, mutta samaan aikaan sinne osui teollisuustyönantajien ja Ammattikasvatushallituksen vaihtoehtoinen ohjelma. Tampereen "punaisessa" yliopistossa se kuitenkin näytti etenevän parhaiten Hämeenlinnan Opettajankoulutuslaitoksessa (HOKL) yhteistyössä Ammattikoulujen Hämeenlinnan Opettajaopiston $(\mathrm{AHO})$ kanssa: työelämään ja ammatteihin orientoituvan kasvatustieteellisen koulutuksen ja tutkimukseen reviiriksi muodostuivat HOKL:iin perustetut ammattikasvatuksen virat ja toiminnot. Aikuiskasvatus-oppiaine levisi 1980-luvulta lähtien myös kuuden muun yliopiston kasvatustieteiden tiedekuntien kasvatustieteiden laitoksiin. Virkoihin rekrytoitiin lähinnä psykologeja ja kasvatustieteilijöitä. (Heikkinen 2011; Tuomisto 2011).

Vaikka eri aikuiskasvatuksen tutkimus- ja koulutustehtävissä toimineiden kokemuksia ei ole systemaattisesti koottu, kuvittelen kuitenkin niistä hiukan tietäväni yli 20-vuotisen työ- ja luottamustehtävähistorian perustalta. Nykyvaihetta esileikittiin tosissaan, kun suomalaisia yliopistoja eurooppalaistettiin opetus- ja kasvatusalan massiivisessa VOKKE-hankkeessa 2000-luvun puolivälissä. ${ }^{2}$ Vaikka aikanaan käenpoikasena yliopistolliseksi kelpuutettu (luokan) opettajankoulutus, mukaan lukien varhaiskasvatus, talloi volyymiltään ja työelämärelevanssiltaan marginaalisen kasvatustieteen jalkoihinsa mennen tullen, aikuiskasvatusta eivät muistaneet edes sen omat tutkijat. Ehkä yhdet eivät asiaa ymmärtäneet ja toiset pitivät osallistumista turhana, kun pedagogisen pätevöittämisen ja konsultatiivisen koulutuksen ehtymättömät markkinat näyttivät siivittävän oppiaineen menestystä hamaan tulevaisuuteen.

Nykyisessä tutkintojen ja tutkimuksen EU-eurooppalaisen harmonisoinnin huumassa yliopiston ja tieteen historiasta häiritsevästi muistuttavat oppiaineet joutavat romukoppaan. Toistuvissa sisällöllisissä ja henkilöstöpuhdistuksissa sen enempää tiede- kuin käytäntöyhteisötkään tuskin jaksavat provosoitua aikuiskasvatuksen katoamisesta laajaalaisiin osaamis- ja ongelmalähtöisiin tutkinto- ja tutkimusohjelmiin.

\section{KUKA MEITÄ KÄSKEE?}

Vielä syksyllä 2010 suomalaiset yliopistouudistuksen toimeenpanijat maalailivat henkilöstön ja opiskelijoiden silmiin ihanaa tulevaisuutta, joka tehdään yhdessä ja kaikkia kuunnellen. Mitään entisestä hyvästä ei menetettäisi, mutta uutta olisi luvassa yllin kyllin. Vuoden alussa rakenneuudistus oli paketissa, rehtorien nimittämät johtajat ohjaksissa, ja ainakin Tampereella kellosta alkoi kuulua Lehikoisen tuttu ääni:

"Yliopistolaisilla on edessään vanhasta irrottautuminen ja uuteen tarttuminen. Rakenteiden uudistaminen ei tuota tulosta, jos toimintakulttuuri ei muutu tai jos ei olla valmiita joustamaan yhteisten päämäärien hyväksi. Tieteenalayksiköiden johtajat on valittu ja vaikka johtajavalinta ei olisikaan mennyt oman toiveen mukaisesti, ei pidä vaikeuttaa valittujen johtajien työtä turhalla rutinalla. Siispä pulinat pois ja tartutaan työhön. Johtajien tehtävänä on ottaa johtajuus haltuun ja johtaa yksikköä, ja siellä toimivien tehtävänä on auttaa häntä siinä, sillä hyvä johtaminen on kaikkien etu. Ilman työyhteisön tukea johtajan työ muodostuu mahdottomaksi, yrittipä hän sitten johtaa edestä, takaa, sivulta, keskeltä, vierestä, ylhäältä tai alhaalta.” (Rehtoriblogi 18.1.2011).

Oli odotettavissa, ettei Aikuiskasvatus-lehti aikuiskasvatusoppiainetta koskevaa keskustelua käynnistäessään polta näppejään yhdistämällä sitä yliopistojen ja kasvatusalan yksiköiden meneillään oleviin muutoksiin. Avauksissaan päätoimittaja Heikki Silvennoinen erottaa turvallisesti toisistaan aikuiskasvatustieteen ja aikuiskoulutustutkimuksen. (Silvennoinen 2010a, 2010b). Hän toteaa aikuiskoulutuksellisen kilpavarustelun eriarvoistavan erityisesti tilapäistä, köyhää, työtöntä ja alityöllistettyä työvoimaa. Valtion keskusvirastojen vetäytymisen - erityisesti opetus- ja kulttuuriministeriön aikuiskoulutuksen tulosyksikön karsimisen ja hajauttamisen korkeakoulutuksen, yleissivistävän ja ammatillisen koulutuksen osastoille, eli kettujen ja kanojen asuttamisen samaan tarhaan - koulutuspolitiikassa hän arvelee jättäneen aikuiset, aikuiskouluttajat ja tutkijatkin hajaannuksen tilaan.

Onko meistä hyvinvointivaltion syleilyssä todella tullut näin hallintoaddikteja? Toisaalta taloudellisen, sosiaalisen ja kulttuurisen pääoman kasaajat ovat vahvimmilla kisassa tieteen, tiedon ja kasvatuksen määrittelyvallasta. Kun aikuiskasvatustieteen nimissä esiintyvät ovat siellä heikoimmilla, eikö ole 
kohtuutonta osoittaa vain heille vaatimus aikuiskoulutuksen ja elinikäisen oppimisen suhteuttamisesta yhteiskunnalliseen järjestykseen ja hallintaan, luokkarakenteeseen sekä hyvinvoinnin, resurssien ja vallan jakautumiseen. Onko liian delikaattia muistuttaa siitä myös pääoman kasaamisessa paremmin pärjääviä aikuiskoulutuksen tutkijoita?

\section{KETÄ ME EI OLLA}

Aikuiskasvatus-lehden kannanotoissa alan tutkimuksen ja tieteellisen diskurssin odotetaan ensisijaisesti erottautuvan akateemisilla kentillä. Aikuiskasvatuksen tulkitaan tyypillisesti ja yhdysvaltalaisia esikuvia noudatellen tieteellistyneen ja professionalisoituneen nelivaiheisesti. Ensin muodostui käytäntö - Suomessa vapaa kansanvalistus- ja sivistystyö -, jossa toimivien perustietoja ja toimintamalleja kehittämään syntyi toiseksi korkeakoulutasoinen opinala - Suomessa 1920-luvun lopulta lähtien kansansivistysoppi. Kolmannessa vaiheessa perustettiin käytäntöjä käsitteellistävä ja teoretisoiva tutkimus - jossa Suomessa nojattiin yhteiskuntatieteisiin ja filosofiaan. Neljännessä metatieteen vaiheessa aikuiskasvatuksen tutkijat alkoivat tutkia ja reflektoida omaa toimintaansa. (esimerkiksi Tuomisto 2011).

Aikuiskasvatus-lehden toimituskunta (Filander ym. 2010) lisää akateemisten tekijöiden vaikutukseen myös ulkopuolisia historiallisia tekijöitä, kuten teollistumisen, nationalismin ja työväenliikkeen nousun. Vaikka tilaa olikin vähän, muuan lause tai kirjallisuusviite niiden konkreettisista vaikutuksista aikuiskasvatustieteeseen ei olisi tehnyt pahaa. Myös väite aikuiskasvatustieteestä turvaamassa väestön kasvattamista ylhäältä annettujen tavoitteiden mukaisiksi toimijoiksi kaipaisi evidenssiä.

\section{TYHMÄ JA LATTEA KÄYTÄNTÖ}

Niin Kristiina Brunila (2010) kuin toimituskunta (Filander ym. 2010) toteavat kirjoituksissaan, että päivittäisen työn ja kasvatuksen kieli ei tarkoita mitään tai tarkoittaa päinvastaista kuin uskotellaan: se on projektimyllyjen, diktatuurien ja organisaatioiden loitsumaista, kokemuksia kylmästi sopeuttavaa kommunikaatiota. Epäilemättä hallinnon teksteillä vaikutetaan käytännön toimijoiden ja tutkijoiden kieleen ja tieteelliseen arkiajatteluun. Oletan silti käytävä- ja kahvipöytäkeskustelujen viestivän ihmisten tyhmyyden ja latteuden sijasta kyynistymisestä, turhautumisesta ja toivottomuudesta, joita esimerkiksi alan "johtavat toverit", edustukselliset elimet tai tieteelliset seurat eivät näytä ottavan vakavasti. Useimmat tietävät hyvin, että yliopistoissa esiinnytään ja tuotetaan tehokkuuden vaikutelmaa mielekkyyttä rakentavan keskustelun sijasta. Vaikuttaa kaksinaismoralistiselta julistaa soluttautuminen akateemisen kapitalismin järjestelmän sisälle poliittiseksi uroteoksi ja saman tien syyllistää sen ylläpidon ja pääoman kasaamisen kontrollista projektien johtajia ja professoreita. Ketkä ja millä perusteella kelpaavat kriittisten tutkijoiden joukkoon ja millä perusteella he ovat etuoikeutettuja tekemään tulkintoja ja puhumaan sorrettujen ja osattomien puolesta? (vrt. Kirchhöfer ym. 2007; Furedi 2006)

Toimituskunta katsoo aikuiskasvatusoppiaineen tieteellisyyden muiden kasvatustieteiden tapaan perustuvan sen yhteiskuntatieteellisyyteen, mikä mahdollistaa oikeat tulkinnat käytäntöjen taustalla ja ulottumattomissa olevasta "todellisuudesta":

"Arkikäsitykset yhteiskunnallisesta todellisuudesta (myös siitä, joka on aikuiskasvatustieteen tutkimuskohdetta) ovat jatkuvan kamppailun kohde. Eri lähtökohdista laaditut tulkinnat törmäävät, eikä asiaan vähemmän perehtynyt ja tulkintojen lähtökohtaoletuksia tuntematon aina osaa ottaa kantaa eri tulkintojen oikeellisuuteen implikaatioineen... Tässä maastossa aikuiskasvatustieteen pitäisi kyetä tarjoamaan tieteellinen tulkinta yhteiskunnallisesta todellisuudesta." (Filander ym. 2010, 214.)

Aikuiskasvatuksen eurooppalaisen tutkimusseuran (ESREA) RELA-journalin ${ }^{4}$ mission tapaan todetaan, että tulosohjausdiktatuurissa "ei liene syytä kokonaan hankkiutua eroon esimerkiksi suomenkielisistä opinnäytteistä, suomeksi ajattelemisesta, suomeksi tutkimisesta". (emt.). Samalla valitetaan, että luokitteluissa ja olemuskielessä pysyessään aikuiskasvatustieteilijät eivät ole omaksuneet yhteiskuntatieteistä kriittistä asennetta, vaan juoksevat muodin mukaan vaihtuvien puhetapojen perässä vastaamassa milloin mihinkin haasteisiin. ${ }^{5}$ Kirjoituksessa perätään latteuden kielioppia vastustavaa radikaalia ajattelua, jossa kysytään "minkälaiseen maailmaan uudet puhetavat ovat meitä johdattelemassa." 
Tutkijoiden ei kuitenkaan arvella tarvitsevan itsekritiikkiä omista syötteistään "uusiin puhetapoihin." Aikuiskasvatustutkimuksen väitetään teknologisoituneen, instrumentalisoituneen ja elitisoituneen ja suuntaavan pä̈huomionsa menestyjiin ja huippuihin, joiden avulla toimintajärjestelmien ja oppivien organisaatioiden henkilöstöresurssit ja hiljaiset taidot on saatu optimaalisesti hyötykäyttöön. Kun suurin osa alan tutkimuksesta tehdään opinnäytteinä, joissa tutkijat yleensä yrittävät kuvata ja tehdä ymmärrettäväksi aikuisten kasvun ja aikuiskasvatuksen todellisuutta, olisi ollut tarpeen saada joitakin empiirisiä faktoja väitteiden tueksi.

Toki opinnäytetutkimukset ovat fragmentaarisia ja saavat marginaalisesti akateemista tukea, puhumattakaan kiinnostuksesta niiden syntetisointiin ja teoretisointiin. Miten laajaa ja merkittävää kehittämis- ja konsultatiivinen tutkimus kuitenkaan oikeasti on? Onko myöskään "modernisaation myötä" tutkijoiden rooli todella tullut jatkuvan kehittämisen, innovatiivisuuden ja oppimisen tehostamisen eetoksen leimaamaksi?

\section{PAHAT MARKKINAT JA LIKAINEN POLITIIKKA}

Vaikka globaalia kapitalismia pidetään yleisesti oikean ja aidon aikuiskasvatustutkimuksen perimmäisenä uhkana, konkreettinen kritiikki - puhumattakaan tutkimusperustainen - sen vaikutusmekanismeista on vähäistä. Usein se jää toteamuksiin ammatillisen aikuiskoulutuksen saamasta liiasta huomiosta ja tuesta. (Heikkinen ym. 2011.) Risto Rinne haastaa aikuiskasvatustutkijoita näkemään ja näyttämään, mitä aikuiskoulutuksen liturgian alla todella tapahtuu. Hänen mukaansa (tutkijoiden?) vuonna 1993 toteama trendi tutkimuksen kiinnittymisestä ammatilliseen aikuiskoulutukseen, oppimisprosesseihin, psykologiaan ja didaktiikkaan jatkuu aikuiskoulutuksen yhteiskunnallisten - taloudellisten ja poliittisten - yhteyksien sijasta. "Aikuiskasvatustutkimusta läpäisee jäännöksettä hyödyn, sovellutusten ja välittömän tulosvastuun taakka" (Rinne 2010). Ammatillisen aikuiskasvatustutkimuksen eli kehittämis- ja kokeilutoiminnan katsotaan laajentuneen ammattikorkeakoulujen resursoinnin myötä. Samalla tutkimus on sirpaloitunut ja me- nettänyt näköalaansa, laaja-alaisen ja kauaskantoisen perustutkimuksen asema on huonontunut ja tutkimuksen ja kehittämisen raja on hämärtynyt.

Kaikkein merkittävimmän aikuiskasvatustieteen ja -tutkimuksen haasteen asettaa useimpien kommentaattoreiden mielestä likainen uusliberalistinen politiikka. Rinteen mukaan aikuiskoulutuspolitiikan ja -tutkimuksen arjessa eletään noidankehässä, jossa olemassa olevien aikuiskoulutusinstituutioiden ja sektorirakenteiden välinen yhteistyö, poliittinen näkyvyys ja käytössä oleva data eivät kohtaa kuin sattumoisin siellä täällä. (Rinne 2010.) Hänen aikuiskasvatusta profiloivaksi pitämältään elinikäiseltä oppimiselta puuttuu - brittitutkijoiden arvioita mukaillen - institutionaalinen perusta, professionaalinen identiteetti, hallinnollinen sijainti ja poliittinen profiili.

Toimituskunta (Filander ym. 2010) arvelee, että aikuiskasvatustutkimuksen kohdennus perustuu rahoittajien intresseihin. Näiden odottamien tutkimustapojen ei katsota vastaavan tieteellisessä koulutuksessa hankittuja tutkijakompetensseja ja tieteellisen tutkimuksen periaatteita; kriittistä aikuiskasvatustutkimustutkimusta arvellaan tehtävän liian vähän. Kummastakaan väitteestä ei kuitenkaan esitetä empiirisiä väitteitä: oman kokemukseni perustalta tutkijakompetenssien käyttö ja kriittinen tutkimus ei yliopistossa ole toistaiseksi ollenkaan kiellettyä. Mikään ei vaadi koulutuskysymysten yksilöllistämistä oppimisen kysymyksiksi ja oppimisen tulkitsemista "huippuosaamiseksi kansallisen kilpailukyvyn" palvelijaksi. Jos tutkijoita ei kiinnosta koulutuksen loitontuminen sen ns. sivistyksellisistä tehtävistä ja yhteisöllisyyden kontekstista eikä heitä huoleta käsitteiden omaksuminen rahoittajilta, ehkä syyllisiä ei tarvitse etsiä yliopiston ja tieteenalayhteisön ulkopuolelta.

\section{ME OLLAAN SANKAREITA KAIKKI}

\section{Hyvän puolesta pahaa vastaan}

On hieman epäselvää, onko toimituskunta (Filander ym. 2010) puolesta vai vastaan todetessaan, ettei aikuiskasvatustieteen erityisyyttä pitäisi enää määritellä iän tai elämänvaiheen perustalta. Se toteaa, että tarvittaisiin yhteiskuntateoreettista perustutkimusta 
uudenlaisesta työstä, taloudesta ja aikuisuudesta, varsinkin kun opetus- ja kulttuuriministeriön katsotaan toimillaan käsitteellisesti hävittäneen aikuisuuden ja aikuiskoulutuksen.

On totta, että elinikäisen oppimisen politiikka ja diskurssi ovat luoneet markkinat esimerkiksi ohjauksen ja arvioinnin opeille ja asiantuntijuudelle. Ehkä aikuiskasvatustutkimusta ei kuitenkaan tarvita vain tutkijoiden (?) identifioitumisen takia ja sairaiden ja avuttomien vanhusten puolustamiseen, vaan aikuiskasvatuskäytäntöjen ja -politiikan sekä itse tieteenalan muutosten realistiseen ymmärtämiseen. Myös identiteettiä voisi etsiä muualta kuin työn, talouden ja yhteiskunnan perustutkimuksesta, jota kyllä olisi syytä hyödyntää ja jonka tekijöiden kanssa hankkiutua yhteistyöhön.

Risto Rinne (2010) haluaisi aikuiskasvatustieteen etenevän Kosti Huuhkan kunniakkaan väitöstutkimuksen tiellä ja palaavan yhteiskunta- ja humanististen tieteiden helmaan, tutkimaan aikuisväestön kasvun ympäristöä, rajoja ja mahdollisuuksia. Hieman yllättäen tästä seuraa vaatimus tutkia (universaalia?) episteemistä siirtymää modernista kasvatusparadigmasta - koulutuksesta - jälkimoderniin kasvatusparadigmaan - elinikäiseen oppimiseen. Tiedämme kyllä, että kyseessä on uusliberalismin oppimiseen vannova markkinamalli, joka on korvannut sosiaalidemokraattisen hyvinvointipolitiikan. Kokemukseni mukaan joustavien oppijoiden ja uusien uljaiden ihmisten maailmalle on jo vuosia esitetty näitä oikeampia, tärkeämpiä ja vaikeampia kysymyksiä, aina opiskelijoiden esseitä ja gradujen johdantoja myöten. Pitäisikö politiikkapapereiden, OECD:n tuottamien aineistojen ohella paneutua myös aikuisten kasvun ja kasvatuksen sekä politiikantekemisen prosesseihin ja toimijaverkostoihin? Rohkaisevaa on toki, että Risto vetoaa arvokkuuteemme tutkimusyhteistyön ja voimien jakamisen puolesta, vaikkei lupaakaan siitä "meille" palkintoja.

\section{AKATEEMISEN KAPITALISMIN ISKURITYÖLÄISET MATKALLA A-LIIGAAN}

Puhdistukselta välttymisen ehdot eivät akateemisessa kapitalismissa näytä juuri tieteellistä sosialismia kummemmilta. Tutkijan kelpaamisen kriteereistä tärkeimpiä ovat tieteellisiin aikakauslehtiin perustuva julkaisujen määrä, sitaatiot ja Nobel-palkinnot. (vrt. Mustajoki 2010.) Vaikka tieteenalojen julkaisuperinteiden ja keksintöjen tuotannollisten sovellusten kannalta ne vaikuttavat mielekkäiltä vain lääke- ja luonnon- ja teknisissä tieteissä, jos sielläkään, ovat aikuiskasvatustutkijat näennäisestä kriittisyydestä huolimatta innolla leikissä mukana. Tieteenalalle sopivampien kriteerien yhteisen luomisen ja puolustamisen sijasta tutkijat rakentavat kilpailevia ryhmiä - mitä suurempia, sitä parempia -, jotka pystyvät maksimoimaan eri kokoonpanoissa julkaisemisen ja itseensä viittaamisen. Ylipääsemättömältä insentiiviltä näyttää kuitenkin kilpailun yliopistokohtaisuus, joka luokittelee henkilöstön niin yliopistojen kesken kuin sisälläkin. (Larsson 2011.)

Turun yliopiston koulutussosiologian yksikkö julkaisi vuoden 2011 alussa erityisesti Tampereen yliopiston kasvatustieteilijöitä imartelevan yliopistojen välisen tulosvertailun. Kasvatustieteiden yksikön johtaja onnitteli välittömästi "meitä" kaikkia:

"Vertailumenestys kertoo hyvin tekemästämme työstä ja antaa osaltaan erinomaiset lähtökohdat kasvatustieteiden yksikön tulevaisuuden luomiselle. Mittarimenestys ei tietenkään ole mikään itseisarvo; silti meidän kannattaa yhdessä analysoida tämänkertaisen menestyksemme syitä ja analyysimme pohjalta suunnata ja kehittää toimintaamme niin, että pärjäämme myös jatkossa ... Selvityksen viesti on jotakuinkin seuraava: julkaistaan vertaisarvioiduissa, mielellään $u l k o-$ maisissa tiedelehdissä, laaditaan hyviä rahoitusanomuksia Suomen Akatemialle, tehdään onnistuneita tutkijarekrytointeja ja koulutetaan tohtoreita suunnilleen entiseen malliin. Emme ole yleensä tottuneet pitämään itsestämme ja osaamisestamme meteliä niin kuin jotkut muut julistaessaan itse omaa erinomaisuuttaan. Eikä menestyksestä nytkään kannata "tehrä numeroo", ainakaan liian suurta, mutta aivan aiheesta voimme joka tapauksessa olla ylpeitä kohti A-luokkaa johtaneesta, yhdessä hyvin tekemästämme työstä. Ja ainakin tulosneuvotteluissa kannattaa muistuttaa raportin kirjoittajien sanoista: 'Strategisessa päätöksenteossa on tietysti viisasta turvata 20 yksikön 'parhaalle A-ryhmälle' kansainvälisen tason edellytykset'." (Vuosisuunnitelma 2011,49).

Aikuiskasvatus-lehden puheenvuoroissa Ari Antikainen (2011) luottaa siihen, että Suomessa aikuiskas- 
vatuksen "tutkimuksen tietoperinne on onnistuneesti ajantasaistettu”. Hän laskee tämän osin kriittisen ja feministisen pedagogiikan, mutta - tekemällä rinnastuksen aikuiskoulutukseen osallistumiseen - ennen kaikkea uuden osallistutkimuksen ansioksi. Kun elämänkulun, habituksen ja opiskelijaidentiteetin käsitteet on aikuiskasvatuksen tutkimuksessa jo ajat sitten omaksuttu aineellisten, sosiaalisten ja kulttuuristen resurssien käsitteistön tueksi, olisi ollut kiinnostavaa saada tulkintoja niiden toimivuudesta ja toimivuuden syistä. Ari lohduttaa tutkimuksen epätasapainoisuudesta ja energian tuhlauksesta huolehtivia: yhdistyneenä palaute- ja ajoitusherkkyyteen ne voisivat nostaa aikuiskasvatustieteen autopoieettisten luonnontieteiden rinnalle. (emt.).

Myös Petri Salo (2011) ja Jukka Tuomisto (2011) pitävät disiplinaarista hajaantumista myönteisenä, sillä sen myötä aikuiskasvatustutkimus on lisääntynyt ja monipuolistunut.

Puheenvuoron käyttäjistä suurin osa tunnistaa "oikean, aidon ja kriittisen" aikuiskasvatustutkimuksen vastakohtana ammatillisen aikuiskoulutus- ja ammattikorkeakoulututkimuksen. Toimituskunta (Filander ym. 2010) lataa kuitenkin odotuksia ammattikorkeakouluissa omaksuttuun Learning by Development-lähestymistapaan (LbD). Se mahdollistaisi kasvatuksellisten, taloudellisten, poliittisten ja sosiaalisten tulkintojen kohtauttamisen. LbD:ssä uusien oppimisideoiden toivottavuutta, toteutettavuutta ja toimivuutta peilataan olemassa olevan ymmärryksen ja käytännön reunaehtoihin sekä kypsytellään omaleimaista tutkimus- ja kehitystyön metodologiaa. Aikuiskasvatuksen uusien tiede- ja tietokäsitysten menestyksen uhkana näyttäytyvätkin tällöin tieteen reviirin perinteiset vartijat. Jos yliopistoissa onkin oltu vähän jälkijunassa, nyt mennään ammattikorkeakouluista oikealta ohitse laaja-alaisissa, käytännöllisesti relevanteissa tutkinto- ja tutkimusohjelmissa, joissa oppiaineiden rajat häivytetään. Vaikka asiasta ei tehdä numeroa, taustalla on "uusi” tietokäsitys, joka preferoi situationaalista, hyödynnettävää tietoa. Sitä määritellään, tuotetaan ja arvioidaan paikallisesti, ilman disiplinaaristen traditioiden rasitteita. Kyse ei enää ole perinteisestä monitieteisyydestä tai käytännöstä asettuvasta poikkitieteellisen tiedon ja tietämisen haasteesta, joka kyseenalaistaisi valta- virtatutkimuksen tiedon määritelmät, tuotannon ja arvioinnin. (vrt. Anttila 2006, Nokelainen 2009.)

Aikuis- (ja ammattikasvatus)tutkimuksen menestystä on ennenkin haettu kulloinkin muodikkailta ja myyviltä opinaloilta. Kantaisien filosofis-historiallisten saarnojen tunnollisesta kuuntelusta huolimatta suosituin lienee ollut psykologia - psykotekniikoina sekä tavoite- ja itseohjautuvan, emansipatorisen, ekspansiivisen ja konstruktivistisen oppimisen oppeina. Aikuiskasvatus-lehden puheenvuorojen mukaan hyvä kakkonen on sosiologia, joka psykologian perässä kurottelee akateemisille statusmarkkinoille.

Jo monen sesongin menekkituote on ollut tietotekninen mediapoetiikka ranskalaisilla ja rihmastoilla. Sen mukaan vain hierarkiattomissa, auktoriteetittomissa ja hyperkonnektiivisissa tietoteknisssä verkostoissa voidaan edistyksellisesti tutkia elinikäistä oppimista. Tutkimus, jonka lähtökohtana on totuuden etsinnän sijasta halu, olisi kykenevä käsitteellisesti tavoittamaan itseään vastaavan yhteiskunnan ja edistämään sen todellistumista. (esim. Usher 2010).

\section{TARVITAANKO MEITÄ?}

Suomalaisen aikuiskasvatustieteen muotoilu ei ehkä noudattanut sosiaalipsykologian ylikansallista levitysprojektia. Onhan alan opettajilla, tutkijoilla ja opiskelijoilla perinteisesti ollut läheinen yhteys kansallisiin käytäntöihin ja politiikkaan, myös sen profiloituessa ammattikasvatukseen. Vaikka aikuiskasvatustiede yleisesti soveltaa sosiologiaa ja psykologiaa, ehkä filosofiaakin, se herättää "perustieteissä” vielä vähemmän kiinnostusta kuin kasvatustiede. Kun oppiaineelle tuli kasvatustieteiden tiedekuntia laajennettaessa kysyntää muissa yliopistoissa, sai Tampereen yliopiston perinne - varsinkin mielleyhtymineen 1970-luvun sittemmin haaksirikkoutuneeseen yliopistoradikalismiin väistyä ajankohtaisten valtakamppailujen tieltä. Niissä kelpaaminen ja voittaminen edellyttivät kiinnostuksen siirtämistä yhteiskunnallisista liikkeistä ja aikuiskasvatuskäytännöistä yleisiin koulutuspoliittisiin - erityisesti korkea-asteen koulutuksen - teemoihin, henkilöstön kehittämiseen ja konsultointiin sekä työn oppimisen ja johtamisen tehostamiseen niin koulutuksessa kuin työpaikoilla. Sillan rakentamisen sijasta aikuiskasvatustiede alkoi antaa toiminnan ja uran rakenta- 
misen tiloja perustieteiden ankaraa kilpailua välttäville, ajan markkinahenkeä haisteleville ja uusia professioita oikeuttaville ryhmille.

Aikuiskasvatus on tiedettä spesifioivana terminä yhä useammassa maassa kadonnut kokonaan tai korvautunut aikuisten/elinikäisellä oppimisella tai jatkuvalla koulutuksella. Pohjois-Amerikassa ja Aasiassa terminologia edelleen elää, Saksassa ja ItäEuroopassa andragogiikan nimissä. Ehkä suomalaista aikuiskasvatusta on tähän asti varjellut sen joustavuus, opportunismi ja sopeutuminen muutoksille, mutta yleisesti ottaen niillä on yliopistoissa hintansa. Terveys- ja sosiaalialan ja kirkollisten organisaatioiden ohella työntekijöiden uupuminen, turhautuminen ja kiusaaminen ovat pahimpia yliopistoissa. Yliopistouudistuksen ja sen jälkeisten yliopistokohtaisten "rakenteellisten uudistusten" seurannat osoittavat, että suurin osa tutkimus- ja opetustyötä tekevistä voi entistä huonommin ja monet haluaisivat päästä pois. (Esimerkiksi Puhakka ym. 2011.)

Richard Münch (2009) tulkitsee yliopistojen noudattavan henkilöstöpolitiikassaan potkupallofirmojen logiikkaa: kauppaa käydään parhaista pelaajista, joita voidaan hyödyntää kansallisissa ja kansainvälisissä liigaotteluissa. Parhaille luvataan tutkimisen vapautta, tutkimusapulaisia, hallinnollista tukea, paremmat työ- ja tutkimusolosuhteet, palkka-, työsuhde- ja muita etuuksia. "Soppakeittiön" työläiset saavat hoitaa huonomman opiskelija-aineksen massaopetuksen.

Äkkiseltään suomalaisia olosuhteita ei uskoisi optimaalisiksi potkupallossa pärjäämiselle, mutta silti huippusarjaan pyritään hankien keskelläkin jättämällä työsuhteita täyttämättä, ulkoistamalla opetusta väliaikaisille ja tuntipalkkaisille ja karsimalla akateemisen jälkikasvun työsuhteita. Projekteja ja projekteista riippuvaisia tutkijoita lisätään ja aloittavista tutkijoista tehdään koululaisia. Oligarkkisessa yliopistossa edes muodollisesti ja retorisesti ylläpidetyt uskomukset akateemisesta eetoksesta, keskinäisestä luottamuksesta ja arvostuksesta väistyvät kaikkien kamppailulla kaikkia vastaan. Tieteenalojen ja tutkimuskohteiden oikeuttamisessa kaikki keinot ovat sallittuja, vaikka kilpailijoiden voimavarat ja olosuhteet ovatkin erilaiset. Kilpailun huumassa myös akateeminen doping - keinottelu, kartellit, mono- polit - käy selviytymisen ja menestymisen kannalta yhä välttämättömämmäksi. Entistä sisäsiittoisemmat ja sisäänpäin lämpiävämmät yksiköt keskittyvät kartellinsa taloudellisen, sosiaalisen ja kulttuurisen pääoman kasaamiseen, jolloin erilaisen ja uuden todellisuutta koskevan tiedon kehittämisen tila kaventuu entisestään. Kun henkilöstön pahoinvoinnissa on kyse akateemisen työn mielekkyysperustan - tieteellisen luovuuden, ajattelun vapauden ja vaikutusmahdollisuuksien - tukahduttamisesta, kuulostavat johtajien kehotukset näin kokeville yliopistosta lähtemiseen vähintäänkin kyynisiltä.

Aikuiskasvatustieteen ja -tutkimuksen olemassaolon ja identiteetin kannalta avainasemassa on glokaalin, hegemonisen yliopisto- ja tiedepolitiikan implementoinnin onnistuminen. Kaikkialla maailmassa rakennetaan ylikansallisiin standardeihin (kuten EQF for lifelong learning) sopivia, laaja-alaisia, opiskelijoiden henkilökohtaisista kiinnostuksista ja työllistyvyydestä määräytyviä tutkinto-ohjelmia ja tutkimusmarkkinoihin joustavasti vastaavia tutkimusohjelmia. Radikaalia niissä on irtautuminen tieteenalojen teorian- ja käsitteenmuodostuksesta ja niiden perinteisestä kiinnittymisestä professuureihin. (Münch 2009; vrt. Tampereen yliopisto 2010.) Suomessa ei saksankielisten maiden tavoin ole pitkitetty aineellis-taloudellisista intresseistä vapaan, tutkija- ja tutkimuslähtöisen hengentieteen retoriikan ja juhlinnan ("eetoksen") luhistumista. Uusissa yliopistorakenteissa professorivalta, oppiaineperustainen tutkimuksen tiedonmuodostus ja kysymyksenasettelu näyttää kitkatta muuntuvan voimavaraksi, jota yliopistoyritys hyödyntää kasvattaakseen rahallista ja symbolista pääomaansa. Huipputiedepolitiikassa ei edistetä tiedettä - todellisuutta koskevan uuden tiedon etsimistä -, vaan luodaan akateemista toimialaa, jonka uskotaan tuottavan voittoja. (emt., 191.)

Aikuiskasvatusoppiaineen ja -tutkimuksen erityisyyden tulkinnat jäävät spekulaatioiksi ilman empiiristä poikkitieteellistä ja -kulttuurista tutkimusta. Esoteriaan sortumisen uhallakin perään sen arkeologista ja konkreettis-historiallista analyysiä osana (ihmis)tieteiden järjestystä: mikä (aikuiskasvatustodellisuudessa) teki aikuiskasvatusta koskevan tieteellisen tiedon mahdolliseksi, mikä mahdollisti 
sen muutokset? (vrt. Foucault 2010; Bryant 2011.) Miksi sen esityksiksi ilmestyivät kansansivistysoppi, työnjohto-oppi, ammattikasvatusoppi, mikä ja miten "kutsui" ne muuttumaan aikuiskasvatukseksi, henkilöstönkehittämiseksi, ammattikasvatustieteeksi tai -pedagogiikaksi ja korvautumaan elinikäisen oppimisen ja ohjauksen opeilla? $?^{6}$ En usko tarinoihin tieteellistymiseen toiminta/kasvatuskäytäntöjen jalostamisena tai ulkoisiin voimiin reagoimisena. Arvelen, että kyse oli talouden, politiikan, kasvatuksen ja tieteen toimijaverkostojen ja -liittoutumien ohjelmien toteuttamisesta. (vrt. Heikkinen 2011.) Tarkoitetut ja satunnaiset tapahtumakulut saattavat institutionalisoitua (tilapäisesti) tieteenalan itseymmärrykseksi, joka määrittelee ”aikuiskasvatukseksi” kelpaavia käytäntöjä, ammatillisuuden ehtoja ja ideologisia normeja.

Nykyisissä tieteeksi kelpaamisen ylikansallisissa profilointikamppailuissa kriteereinä pidetään aikuiskasvatustieteen käytännöllistä, markkinataloudellista ja poliittista relevanssia. Julkisin varoin ylläpidetyn tieteen- ja tutkimusalan on kysyttävä myös olemassaolonsa taloudellista, sosiaalista ja moraalista oikeutusta, mutta keneltä? Onko aikuiskasvatus-oppiaineesta luopumiselle tai sen psykologia- tai yhteiskuntatieteellistämiselle vaihtoehtoja? Niin houkutteleva kuin sellaisen rakentamiseksi tarjoutuva kriittinen aikuiskasvatustutkimus onkin, en voi Jussi Vähämäen tavoin olla kysymättä, asettuuko se kohteidensa ja ympäristönsä yläpuolelle:

"(T)utkimuksessa ei ole kyse tutkijan näennäisen sotilaallisesta puolen valinnasta, heikomman puolelle asettumisesta tai tieteestä kansan palvelijana. Tällaiset käsitykset, jotka valitettavasti hallitsevat edelleen ainakin erilaisia fraktioita, toistavat edelleen tutkijan ja tutkittavan, tietäjän ja tietämättömän, erityisosaajan ja maallikon (sekä johtajan ja johdettavan) välisen vastakkainasettelun." (Vähämäki 2010, 117; vrt. Heikkinen ym. 2001.)

Voisiko vaihtoehtoinen tutkimus - aikuiskasvatustieteilijä-subjektin ja tiedettävän objektin erottavan suhteen sijasta - perustua Vähämäen ehdottamaan yhteistyö- ja konfrontaatiosuhteeseen erilaisten välillä? Yhteistutkimuksessa tutkijat eivät olisi sivistysyli- opistossa koulutettuja totuuden vartijoita, jotka puhuvat jonkun (sorrettujen, alistettujen, kansan ym.) nimissä. (Emt., vrt. Kirchhöfer 2007; Furedi 2006.) Koska institutionaalistuneella sanastolla on taipumus tuottaa valtavaikutuksia ja uusintaa olemassa olevia valtasuhteita, tutkimuksessa aikuiskasvatustodellisuutta ("tehdasta") tulisi tarkastella sitä todellistavien käytäntöjen ("tehtaan"), eikä aikuiskasvatustieteen näkökulmasta.

Aikuiskasvatuksen ääriviivoja, rajoja ja omia paikkoja voisi etsiä yhdistämällä tutkijoiden ja käytännön toimijoiden kyvyt tiedon tuottamisessa ja rakentamisessa. Kyseessä ei olisi muodikas yhteinen tiedonrakentelu, jaettu asiantuntijuus tms. "tilanteinen, tilauksiin ja odotuksiin vastaava ja kulloistakin tarvetta tyydyttävä tieto ja tiede”, vaan niin tieteen kuin todellisuuden konkreettisesti haastama tutkimus.

Aikuiskasvatustieteen identiteetin kriteerinä voisi olla kyky yhdistää paikallinen ja alueellinen, naiivi ja käytäntöihin ankkuroitunut tieto tieteelliseen - eri tieteenaloihin perustuvaan - tietoon tuomalla yhteiseen tilaan niin sanotut tutkijat ja kokeneet käytännön asiantuntijat. (Vähämäki 2010.) Se tuskin on mahdollista ilman yhteistä, dekonstruktiivista arkeologista ajattelutyötä. Tieteen identiteetin kannalta tutkimus ja tutkimusmetodologia eivät ole yhdentekeviä. ${ }^{7}$

Aikuiskasvatusta voi epäilemättä tarkastella ehtymättömän moninaisista - liiketaloudellisista, sosiologisista, psykologisista ja niin edelleen - näkökulmista ja tarkoitusperistä. Pauli Siljanderia (2010) mukaillen voi kysyä, eikö minkään tieteenalan tehtävä tai oikeus ole tematisoida aikuisuutta, aikuisten kasvua ja oppimista, kasvatusta ja koulutusta kasvatuksellisesti. Yksikkömme johtaja onkin enteellisesti todennut, että kasvatustieteissä (niin opettajien kuin opiskelijoiden) tieteenaloihin identifioituminen tulee jatkossa jäämään yliopistojen sijasta tieteellisten seurojen huoleksi.

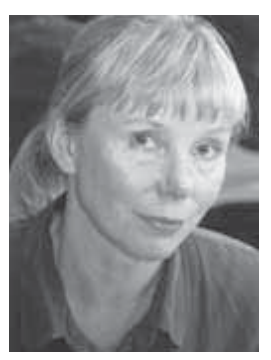

ANJA HEIKKINEN kasvatustieteen professori (elinikäinen oppiminen) Tampereen yliopisto 
Alastalo, M. (2009). Metodisuhdanteiden mahti. Tampere: Vastapaino.

Antikainen, A. (2010). Onko aikuiskasvatustutkimus käännekohdassa? Aikuiskasvatus, 30(2), 130-137.

Anttila, P. (2006). Tutkiva toiminta ja ilmaisu, teos, tekeminen artefakta 16. Helsinki: Akatiimi Oy.

Brunila, K. (2010). Onko tilaa kriittiselle aikuiskasvatuksen tutkimukselle? Aikuiskasvatus, 30( 2), 138-140.

Bryant, L.R. (2011). The democracy of objects. The Open Humanities Press. http://quod.lib.umich.edu/cgi/t/text/textidx?c=ohp;idno=9750134.0001.001

Filander, K. \& Jauhiainen, A. \& Saloheimo, L. \& Silvennoinen, H. \& Valkama, H. (2010). Aikuiskasvatuksen tila ja tulevaisuus. Aikuiskasvatus, 30(3), 213-223.

Foucault, M. (2010). Sanat ja asiat. Helsinki: Gaudeamus.

Furedi, F. (2006). Where have all the intellectuals gone? London: Routledge. $2^{\text {nd }}$ edition.

Heikkinen, A. \& Huotari, V. (2001). Ignoranssi kasvatustieteissä. Kasvatus 1/2001.

Heikkinen, A. \& Teräsahde, S. (2011). Aikuiskasvatus on tutkimuksen ja asiantuntemuksen arvoinen. http:// aikuiskasvatuksentutkimusseura-fi-bin.directo.fi/a Bin/fd10388e7e627a5ff6d5a51e2766ba2a/1318494104/ application/pdf/155110/Aikuiskasvatus_on_tutkimisen_ja_ asiantuntemuksen_arvoinen.pdf/.

Heikkinen, A. (2003). Kansainvälistä konsultointia vai poikkikulttuurista tutkimusyhteistyötä. Manninen, J. ym. (toim.) Aikuiskasvatus tutkijoiden silmin - tutkimusta 2000-luvun taitteessa. Tampere\&Helsinki: ATS ja KVS.

Heikkinen, A. (2010). Suomalainen aikuiskasvatustutkimus kansainvälisessä kentässä. Esitelmä Aikuiskasvatuksen tutkimuspäivät, Itä-Suomen yliopisto 17.2.2010.

Heikkinen, A. (2011). Ammattikasvatuksen opillistuminen. Heikkinen, A. \& Tuomisto, J. (toim.) Aikuiskasvatuksen muuttuvat paradigmat. Helsinki: ATS ja KVS. Ilmestyy.

Kirchhöfer, Dieter \& Steffens, Gerd. (Hg.) (2007). Infantilisierung des Lernens? Neue Lernkulturen - ein Streitfall. Jahrbuch für Pädagogik 2006. Frankfurt am Main: Peter Lang.

Larsson, S. (2010). Invisible Colleges in the Adult Education Research World. RELA 1-2/2010.

Moscovici, S. \& Marková, I. (2006). The making of modern social psychology. Cambridge \& Malden: Polity Press.

Mustajoki, A. (2010). Yliopistojen rankingit - paljon melua tyhjästä. Tieteessä tapahtuu 8/2010.

Münch, R. (2009). Globale Eliten, lokale Autoritäten. Frankfurt am Main: Suhrkamp.

Nokelainen, P. (2009). Pääkirjoitus. Ammattikasvatuksen aikakauskirja, 11(1), 4-7.

Puhakka, A. \& Rautopuro, J. (2011). Huojuva lato - isäntiä ja isäntien varjoja? Helsinki: Tieteentekijöiden liitto. http://www. tieteentekijoidenliitto.fi/news/611

Rehtoriblogi 18.1.2011. http://rehtoriblogi.uta.fi/2011/01/18/nytkun-joulu-mennyt-on-kevat-saapuu/.

Rinne, R. (2010). Historiallinen murros ja aikuiskasvatuksen tutkimus. Aikuiskasvatus, 30( 4), 250-255.
Salo, P. (2011). Maailma muuttui - muuttuiko aikuiskasvatus? Aikuiskasvatus, 31(1), 35-44.

Siljander, P. 2011. Tutkimuksen keskittämispolitiikka ja julkaisukäytänteet. Kasvatus 4/2011.

Silvennoinen, H. (2010a). Tutkimuksen asialla. Aikuiskasvatus, 30( 4) 242-243.

Silvennoinen, H. (2010b). Välittäminen aikuiskoulutuksen tehtävänä. Aikuiskasvatus, 30(1), 2-3.

Tampereen yliopisto 2010. Strategia. http://www.uta.fi/esittely/ strategia/koulutus.htmlTutkinto-ohjelmien perusteet.

Tuomisto, J. (2011). Kansansivistysopista aikuiskasvatustieteeseen. Heikkinen, A. \& Tuomisto, J. (toim.) Aikuiskasvatuksen muuttuvat paradigmat. Helsinki: ATS ja KVS. Ilmestyy 2012.

Usher, R. (2010). Riding in the lines of flight. RELA 1-2/2010

Vuosisuunnitelma 2011. Kasvatustieteiden yksikön vuosisuunnitelma.

Vähämäki, J. (2010). Tieto ulos instituutioista. niin\&näin 4/2010.

\section{VIITTEET}

1 Vaikka kirjoittajat väittävät, että kyseessä oli oppiaineen luonteeseen itseensä perustuva ylikansallistaminen, jota yhdysvaltalaiset tutkijat aidosti tavoittelivat, hankkeen konkreettinen kuvaus antaa kyllä perusteita muihinkin johtopäätöksiin.

2 Ehkä paradoksaalista on se, että hankkeen johtaja ja sihteeri olivat molemmat taustaltaan aikuiskasvatustieteilijöitä.

3 Tässä sitaatissa ja myöhemmin kursivoinnit kirjoittajan.

4 RELA - European Journal for Research on Education and Learning of Adults - on ESREA:n (European Society for Research on Education of Adults) vuonna 2010 aloittanut open access-aikakauslehti. Sen perustamisessa korostettiin vaihtoehtoisuutta angloamerikkalaiselle tiedeimperialismille, mutta kiintoisaa kyllä keskeisiksi arvostuksen kriteereiksi tuli sen edustautuminen lehden toimituskunnassa sekä englanniksi julkaistavien tekstien kieliopillinen ja tyylillinen "riittävyys".

5 Toimituskunnan odotukset aikuiskasvatustutkimuksen yhteiskuntatieteellistämisestä tarkoittanevat diskurssimuotien kierrättämistä nykyistäkin tehokkaammin.

6 On mielenkiintoista, että Kansansivistysopillinen seura muuttui Aikuiskasvatuksen Tutkimusseuraksi 1971 ja että esimerkiksi ESREA on eurooppalainen aikuisten kasvatuksen (koulutuksen) tutkimuksen seura. Kuitenkin ATS on Tieteellisten Seurojen Valtuuskunnan jäsen ja Suomen kasvatustieteellinen seura liputtaa edelleen tiedelähtöisyyttään.

7 Ehkä Petri Salon ajatukset toimintatutkimuksesta ja Jyri Mannisen hahmotelmat kehittävästä (arviointi) tutkimuksesta ovat oman tulkintani kanssa samansuuntaisia. Niitä pyrimme todentamaan VSY:n kanssa käynnistyneessä Sivistystyön Vapaus ja Vastuututkimushankkeessa. http://www.vsy.fi/ 